\title{
SPATIAL DIFFERENTIATION OF SYNTHETIC MEASURE OF ECONOMIC SECURITY OF LOCAL GOVERNMENT. CASE STUDY OF FINANCIAL VARIABLES OF THE CITIES IN THE EASTERN POLAND MACRO-REGION
}

\author{
Paweł DZIEKAŃSKI*, Juliusz PIWOWARSKI** \\ *The Jan Kochanowski University (JKU) in Kielce, Poland, \\ ** University of Public and Individual Security APEIRON, Krakow, Poland \\ pdziekan@interia.eu
}

\begin{abstract}
In this article the authors focus on the element of security culture which is economic security. It is the ability of an economic system to use internal factors of development on a local level and international economic interdependence in such a way that it can guarantee its safe development. Stability and certainty of funding sources determine the scope and level of public services and tasks of a municipality that it fulfils. Economic security is a resulting category that allows to assess functioning of security culture from the perspective of local economy. The aim of the article is to provide determinants of shaping of economic security in Swietokrzyskie Voivodeship municipalities in the context of selected elements of financial management for 2010 and 2015. In the calculations the data of the Central Statistical Office (Local Data Bank) were used. The determined synthetic measure allows to arrange Swietokrzyskie Voivodeship municipalities according to the examined aspect. It gives the basis for evaluation of effectiveness of economic policy instruments that were applied in the past. They provide a comparative picture between the objects that were analysed, allow to indicate weaker and better areas of functioning of a unit.
\end{abstract}

\section{Keywords: economic security; synthetic measure, finance, safety culture}

\section{Introduction}

The complexity of advanced social and economic processes is undisputed. These processes take place in a defined environment, which affect the competitiveness of the region. It is shaped, inter alia, thanks to the processes of financial and economic nature, influencing the spatial order and socio-cultural order, infrastructure and the ecology of the region. The prism of the finance enables, to some extent, a complex assessment of functioning of a given territorial government unit and its abilities of development $[11,16]$. The finance create the basis of the implementation of public tasks and determine the conditions of economic development. They influence the economic situation of the self-government and the achievement of aims or, finally, the ability to meet its obligations and further development funding [1], understood as a process of transformations, both qualitative and quantitative. The financial situation is shaped by, inter alia, the structure of budgetary revenue and expenditure and the amount of taxes and local charges, deficit or budgetary surplus $[8,17]$.

Economic security of a region is the ability of economic system of the region use the factors of development in such a way, that they will guarantee its unthreatened development. In terms of finance, it is a guarantee of the existence and development of the organization. Security and development are two basic dimensions of the existence and good functioning of the territorial units and their communities [2]. The security of the state, as well as the safety of the specific region, should guarantee its stable 
development through rational management, in other words, conscious and planned use of various methods and techniques, which affect the decisions taken by national institutions or organisations best [18]. Safety culture is the whole of settled tangible or intangible acquisition of a human, which creates military and non-military components of human defence and of security of devices and organisations created by him; these elements create its three foundations: mental, socioorganisational and material; it serves the continuity of the development process of a given entity [19].

\section{The aim and method of research}

The aim of the study is to present the possibilities of using synthetic measure to the assessment and recognition of spatial differentiation of the level of economic security on the example of the cities of Eastern Poland macroregion. 70 cities were assessed, with a particular focus on 14 cities with county rights, which were described in the detailed analysis. The data from Central Statistical Office (Local Data Bank) from 2010 and 2014 were used for the calculations. Using selected variables (table 1c) taxonomic indicators of economic security of municipalities were constructed. Some potential variables could not be included in the group of analyzed variables, because some data on the level of cities with county rights are not collected in the Local Data Bank of Central Statistical Office.

Analysing the spatial differentiation concerned with economic security, taxonomic indicators were used: 1) based on Euclidean distance (ED); 2) based on urban distance (UD). The following, simple taxonomic procedure was used:

I. The set of stimulants and destimulants was defined; before applying linear ordering, the destimulant was converted into stimulant with the formula:

$$
X_{i j}=\frac{1}{x_{i j}}
$$

where $\mathrm{X}_{\mathrm{ij}}$ - feature with number $\mathrm{j}$, describing objects $x_{i}, j=1,2 . . p(p-$ number of features); $\mathrm{x}_{\mathrm{ij}}$ - value of the object of number $i(i=1,2 . . n)$ for the feature $X_{j}$ of number $\mathrm{j}(\mathrm{j}=1,2 . . p$; number of objects). After establishing an initial set of variables verification activities were undertaken according to two criteria [12]:

1) variability - features should indicate appropriate variability, in other words should discriminate objects successfully (threshold value for the measurement $=$ $0.10)$;

2) correlation - two features strongly correlated with each other are the carriers of similar information, therefore, one of them is unnecessary (diagonal elements of the matrix R-1 did not exceed 10) [13;3].

Taking into account the first criterion of the mentioned above, no potential diagnostic variables was eliminated from this study. The method of inverted matrix was used in order to discriminate variables, which enabled the elimination of X1 and X8 from the study.

II. Diagnostic variables usually have different titres and different ranges of variation. Therefore, in order to bring the variables to the state in which they are comparable, it is necessary to transform their value in such a way as to obtain values without titres [14]. Standardization of diagnostic variables was made using zero unitarisation method. Stimulants were unitarized according to the equation:

$$
z_{i j}=\frac{x_{i j}-\min _{i} x_{i}}{\max _{i} x_{i}-\min _{i} x_{i}}
$$

where: $\mathrm{i}=1,2, \ldots \mathrm{N} ; \mathrm{j}=1,2, \ldots, \mathrm{p}$ ( $\mathrm{N}$ is the number of objects (municipalities), and $\mathrm{p}-$ number of features); $\mathrm{z}_{\mathrm{ij}}$ - refers to the unitarized value of a feature for a studied unit, $x_{i j}$ - refers to the value of $j$ feature for a studied unit, max - maximum value of $j$ feature, min - minimum value of $\mathrm{j}$ feature [13].

III. On the basis of standardized variables, the measures of economic security were calculated:

1) based on the distance in the real space with a Euclidean metric, according to the formula: 


$$
E D_{i t}=\sqrt{\frac{\sum_{j=1}^{p}\left(1-z_{i j t}\right)^{2}}{p}}
$$

2) based on the distance in the real space with an urban metric:

$$
U D_{i t}=\frac{\sum_{j=1}^{p}\left|1-z_{i j t}\right|}{p}
$$

where: ED/UD - synthetic measure in the studied period, $z_{i j t}-$ features of the structure of the synthetic measure, $p$ number of feature $[15 ; 4 ; 5]$. Indexes $(3) /(4)$ take values from the range $[0,1]$. If the value of an index equalled 0 , then a given administrative unit would be characterized by a maximum value of each of the studied stimulants. The higher the value of the index, the worse the situation.

IV. At the end, the analysis and interpretation of results were done. Studied objects were divided into four typology groups according to the value quartiles. The compatibility of the results achieved were also verified by calculating the Pearson, Gamma, Spearman and t-Kendall correlation coefficient ([6]).

\section{The finance variables and the problem of economic security}

The assessment of financial situation of the municipalities is connected, inter alia, with possibilities of generating income, attracting investors and residents and carrying out investment policy. It is also influenced by: stable strategy of development, its resources, abilities, as well as acceptance of local authorities $[9 ; 10]$. Own income of municipalities characterize development opportunities, they reflect the foresight of the authorities and the economic activity of residents and their holdings. The expenses indicate the aspiration of municipalities to expand their property, contributing to the improvement of the living conditions of the residents and to development [7].

Security becomes a balance of resources, which the region disposes of and which enable to keep high dynamics of qualitative and quantitative transformations. The security understood in such a way enables harmonious development of economy and provides appropriate living standard for the residents of the region.

\section{Synthetic measure of economic security}

Development of contemporary cities is a multidimensional process, which involves numerous operators representing different sectors or types of resources. Current financial situation is a synthetic image of actual level of economic development of a given administrative unit. As it was noticed, the income of municipalities indicate the thriftiness of the councils and the resourcefulness of the residents. The investment expenses indicate the aspiration of municipalities to expand their property, contributing to the improvement of the living conditions of the residents and to general development.

The highest level of this measure of security in 2010 characterized Białystok, Kielce, Olsztyn (2010; ED/UD) and Białystok, Lublin, Krosno, Rzeszów (2014). At the other end of the rankings were Biała Podlaska, Tarnobrzeg, Chełm (2010) and Chełm, Zamość and Biała Podlaska (2014; ED/UD). The value of the index fluctuated in case of ED method between 0.79 (Białystok) to 0.88 (Chełm; n 2010); from 0.76 (Białystok) to 0.88 (Biała Podlaska; 2014). In case of UD method: from 0.65 (Białystok) to 0.81 (Chełm; in 2010); from 0.58 (Białystok) to 0.79 (Biała Podlaska 2014; table 1b). Synthetic measure of financial situation indicates various level of studied units, which is affected by the economic nature of the unit and the function of the region, as well as financial independence, level of own income, local taxes or implemented expenditure.

The assessment of ED measure indicates a decrease of 6 units, increase of 6 units and an unchanged position of 2 units (Białystok, Rzeszów). The most beneficial changes of position in 2014 in comparison to 2010 took place in Tarnobrzeg (change by 4 places; from 13 to 9 ; in 2010 in relation to 2014), Lublin (change by 4 places; from 7 to 3 ) and 
Krosno (change by 3 places; from 5 to 2). The biggest drop of ranking position in 2015 in comparison to 2010 was in Suwałki (5 places; from 6 to 11); Kielce (3; from 2 to 5), Olsztyn (3; from 3 to 6). In case UD method -7 units improved their positions (Lublin: by 4 places; from 6 to 2; Tarnobrzeg by 3; from 13 to 10); 6 units worsened their position (Suwałki: by 4, from 7 to 11; Kielce 3, from 2 to 5; Olsztyn 3, from 3 to 6), 1 unit (Białystok) did not change its position.

In relation 2014 to 2010 , for the synthetic measure of ED, only Suwałki increased their value by 0.005 ; the remaining administrative units had a lower measure: Krosno -0.0072; Lublin -0.076; Rzeszów -0.055; for synthetic measure UD: Suwałki +0.007 ; Białystok 0.105; Krosno -0.141; Lublin -0.163.

An average value of synthetic measure in 2010 came to -0.85 and slightly decreased in 2014: - 0.82 for ED measure and 0.75 in 2010 and 0.69 in 2014 for UD. In 2014 in relation to 2010, the differentiation according to financial situation did not change (standard deviation +0.01 for $\mathrm{ED}$; +0.02 for UD), with the simultaneous increase of the value of the range from 0.09 in 2010 to 0.12 in 2014 for ED (from 0.16 to 0.21 for UD; table $1 b$ ).

In order to check the compatibility of the results achieved by the two methods, the measures of correlation were set, which presented in table 1a; they indicate high compatibility of the achieved results. The value of the correlation between the values of the measures of security amounted 0.998 (2010) - 0.994 (2014). This may suggest that each of the analyzed measures indicates a similar classification of the level of security viewed from the perspective of the behaviour of the financial variables. This may also mean that in the discussed period of time divergence took place and the spatial differentiation of security was quite stable.

In figure 1, correlograms describing relations which take place between taxonomic transformations of the measures of security and their level were presented. A conclusion can be drawn from them that the measures based on Euclidean distance and urban distance were subjected to divergence in the years 2010-2014 - Pearson correlation coefficients, between their relative transformations in the studied period of time and their level, amounted - for the relation ED-dED 0.498; for UD-dUD 0.391 (in 2010, 2014).
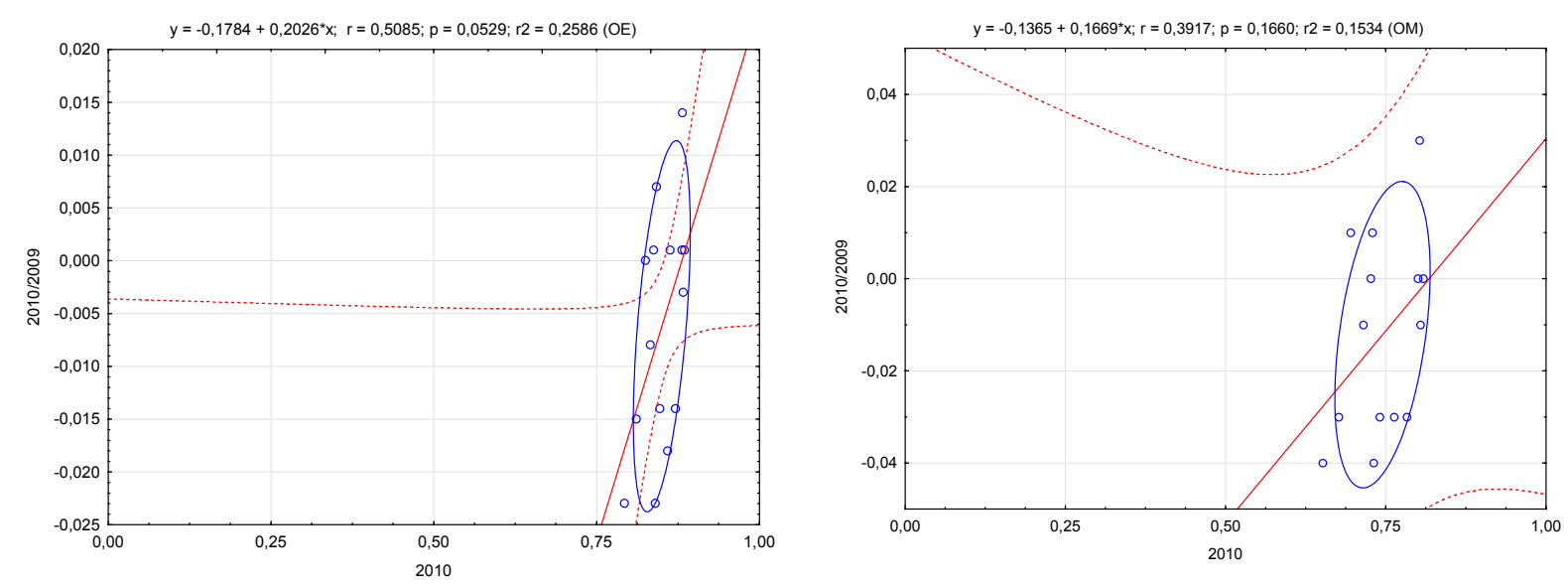

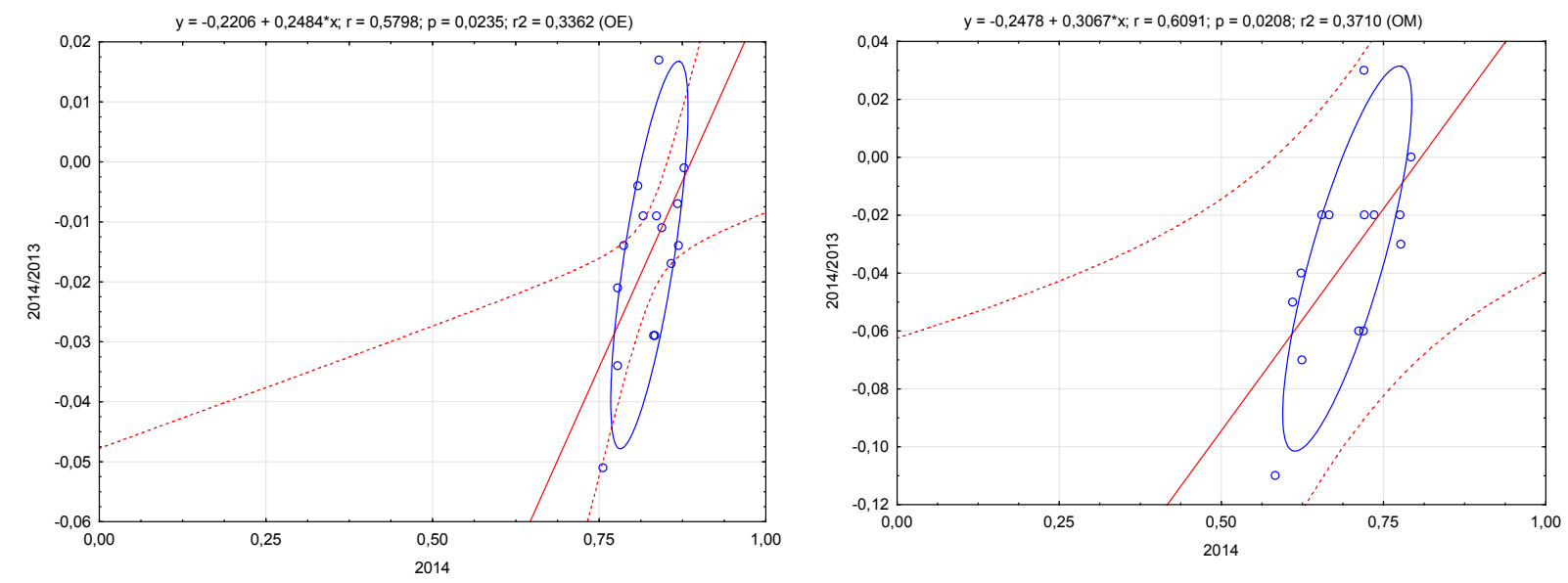

Figure 1: Relative transformations of taxonomic measure of security of a region (financial aspect; in 2010 and 2014).

a) correlation coefficient of taxonomic measure and its transformations

\begin{tabular}{|l|c|c|}
\hline \multirow{2}{*}{} & \multicolumn{2}{|c|}{ ED-UD } \\
\cline { 2 - 3 } & 2010 & 2014 \\
\hline Pearson & 0.998 & 0.994 \\
\hline R Spearman & 0.995 & 0.988 \\
\hline Gamma & 0.978 & 0.956 \\
\hline Tau Kendall & 0.978 & 0.950 \\
\hline & \multicolumn{2}{|c|}{ ED-dED } \\
\cline { 2 - 3 } & 2010 & 2010 \\
\hline Pearson & 0.498 & 0.498 \\
\hline R Spearman & 0.566 & 0.566 \\
\hline Gamma & 0.460 & 0.460 \\
\hline Tau Kendall & 0.449 & 0.449 \\
\hline & \multicolumn{2}{|c|}{ UD-dUD } \\
\cline { 2 - 3 } & 2010 & 2010 \\
\hline Pearson & 0.391 & 0.391 \\
\hline R Spearman & 0.282 & 0.282 \\
\hline Gamma & 0.265 & 0.265 \\
\hline Tau Kendall & 0.248 & 0.248 \\
\hline
\end{tabular}

Table 1: Quartile groups of taxonomic measures and correlation measures b) quartile groups of taxonomic measures of security

c) variables per capita describing economic security

$\mathrm{X} 1$ own income, $\mathrm{S}$,

$\mathrm{X} 2$ income from PIT, PLU, CIT, $\mathrm{S}$,

$\mathrm{X} 3$ tax income, $\mathrm{S}$,

$\mathrm{X} 4$ income from assets, $\mathrm{S}$,

X5 subventions, D

X6 donations, D

X7 capital expenditure, $\mathrm{S}$,

$\mathrm{X} 8$ current expenses, D

$\mathrm{X} 9$ expenses on transport and

communication, $\mathrm{S}$

$\mathrm{X} 10$ expenses on urban economy

and environmental protection, $\mathrm{S}$,

$\mathrm{X} 11$ expenses on housing economy,

$\mathrm{S}$,

X12 local debt, D,

$\mathrm{S}$ - stimulant; D- destimulant

\begin{tabular}{|c|c|c|c|c|}
\hline & \multicolumn{2}{|c|}{ ED } & \multicolumn{2}{|c|}{ UD } \\
\hline & 2010 & 2014 & 2010 & 2014 \\
\hline $\begin{array}{c}\text { A } \\
\text { very good }\end{array}$ & $\begin{array}{ll}\text { Białystok } & 0.793 \\
\text { Kielce } & 0.811 \\
\text { Olsztyn } & 0.825 \\
\text { Rzeszów } & 0.833\end{array}$ & $\begin{array}{l}\text { Białystok } 0.756 \\
\text { Lublin } 0.778 \\
\text { Krosno } 0.778 \\
\text { Rzeszów } 0.787 \\
\text { Kielce } 0.808 \\
\text { Olsztyn } 0.816 \\
\text { Lomża } 0.832\end{array}$ & $\begin{array}{l}\text { Białystok } \\
0.652 \\
\text { Kielce } 0.677 \\
\text { Olsztyn } 0.695 \\
\text { Rzeszów } 0.715\end{array}$ & $\begin{array}{l}\text { Białystok } 0.583 \\
\text { Lublin } 0.610 \\
\text { Rzeszów } 0.623 \\
\text { Krosno } 0.624 \\
\text { Kielce } 0.655 \\
\text { Olsztyn } 0.666 \\
\text { Lomża } 0.712\end{array}$ \\
\hline $\begin{array}{c}\text { B } \\
\text { good }\end{array}$ & $\begin{array}{lc}\text { Krosno } & 0.838 \\
\text { Suwałki } & 0.840 \\
\text { Lublin } & 0.842 \\
\text { Elbląg } & 0.847\end{array}$ & $\begin{array}{l}\text { Przemyśl } 0.834 \\
\text { Tarnobrzeg } \\
0.836 \\
\text { Elbląg } 0.840 \\
\text { Suwałki } 0.844\end{array}$ & $\begin{array}{l}\text { Krosno } 0.727 \\
\text { Lublin } 0.729 \\
\text { Suwałki } 0.731 \\
\text { Elbląg } 0.741\end{array}$ & $\begin{array}{l}\text { Przemyśl } 0.719 \\
\text { Elbląg } 0.720 \\
\text { Tarnobrzeg } \\
0.721 \\
\text { Suwałki } 0.736\end{array}$ \\
\hline $\begin{array}{c}\mathrm{C} \\
\text { weak }\end{array}$ & Łomża 0.859 & - & Łomża 0.763 & - \\
\hline $\begin{array}{c}\text { D } \\
\text { bad }\end{array}$ & $\begin{array}{l}\text { Przemyśl } 0.871 \\
\text { Zamość } 0.881 \\
\text { Biała Podl. } 0.882 \\
\text { Tarnobrzeg } \\
0.883 \\
\text { Chełm } 0.885\end{array}$ & $\begin{array}{l}\text { Chełm } 0.868 \\
\text { Zamość } 0.869 \\
\text { Biała Podl. } 0.878\end{array}$ & $\begin{array}{l}\text { Przemyśl } 0.783 \\
\text { Zamość } 0.800 \\
\text { Biała Podl. } 0.803 \\
\text { Tarnobrzeg } \\
0.804 \\
\text { Chełm } 0.808\end{array}$ & $\begin{array}{l}\text { Chełm } 0.776 \\
\text { Zamość } 0.777 \\
\text { Biała Podl. } 0.793\end{array}$ \\
\hline Minimum & 0.79; Białystok & 0.76; Białystok & 0.65 ; Białystok & 0.58; Białystok \\
\hline Maximum & 0.88; Chelm & 0.88; Biała Podl. & 0.81; Chelm & 0.78; Biała Podl. \\
\hline Range & 0.09 & 0.12 & 0.16 & 0.21 \\
\hline $\begin{array}{l}\text { Interquartile } \\
\text { range }\end{array}$ & 0.04 & 0.05 & 0.08 & 0.10 \\
\hline Variability & 0.03 & 0.05 & 0.07 & 0.10 \\
\hline $\begin{array}{l}\text { Standard } \\
\text { deviation }\end{array}$ & 0.03 & 0.04 & 0.05 & 0.07 \\
\hline
\end{tabular}

ED measure based on Euclidean distance; UD measure based on urban distance; dED - dUD dynamics of transformation of the measure

\section{Conclusions}

The highest level of security, which is measured with the taxonomic indicator, which is the measure of the potential of the third foundation of the culture of security, characterized such cities as: Białystok,
Kielce, Olsztyn (2010) and Białystok, Lublin, Krosno, Rzeszów (2014). Among the units of the lowest level of security were: Biała Podlaska, Tarnobrzeg, Chełm (2010) and Chełm, Zamość i Biała Podlaska (2014; ED/UD). 
The value of the achieved synthetic measure depends from the amount and type of the variables accepted for study. It gives a comparative image in time-space system, enabling to indicate weaker and better areas of functioning of a unit. This knowledge may and should serve local authorities of a region to the assessment of the efficiency of development instruments and tools of financial economy used so far.

Financial condition and the holdings connected with it, which is an important part of the culture of security of a given region, is shaped through the prism of own income, local taxes, subventions and investment expenses. In case of low spatial aggregations, one can come across a deficit of data, usually caused by the lack of representativeness of data, resulting from too small attempt of a study, or even lack of research appropriate for this area. The inference, therefore, should always be carried out with caution, and it is often worth basing the final evaluation on additional studies.

\section{References}

[1] Łukomska-Szarek J., Analiza wskaźnikowa $w$ procesie zarzadzania finansami samorząów lokalnych, Studia i Materiały. Miscellanea Oeconomicae Rok 16, Nr 2/2012.

[2] Dziekański P., Bezpieczeństwo ekonomiczne wyzwaniem wspótczesnego regionu - próba oceny syntetycznej, pp. 121-140 [in:] Kultura Bezpieczeństwa Nauka-Praktyka-Refleksje, WSBPiI „Apeiron” w Krakowie, Nr 16 / lipiec - grudzień 2014.

[3] Walesiak M., Problemy selekcji $i$ ważenia zmiennych $w$ zagadnieniu klasyfikacji, Prace Naukowe AE we Wroclawiu, Taksonomia, pp. 106-118, 12/2005.

[4] Kościelniak P., Szewczyk M.W., Tokarski T., Taksonomiczne wskaźniki rozwoju ekonomicznego województw i powiatów, Wiadomości ststytyczne, 9, pp. 75-97, 2014.

[5] Dziekański P., Spatial Differentiation of the Financial Condition of the Świętokrzyskie Voivodship Counties, Barometr Regionalny, Tom 14 nr 3, pp. 79-91, 2016.

[6] Zeliaś A., Malina A., O budowie taksonomicznej miary jakości życia. Syntetyczna miara rozwoju jest narzędziem statystycznej analizy porównawczej, Taksonomia z. 4, 1997.

[7] Sobczyk A., Finansowanie rozwoju gminy z dochodów własnych, ZN SGGW, Ekonomika i Organizacja Gospodarki Żywnościowej, 77, pp. 137-149, 2009.

[8] Brol R., Rozwój lokalny - nowa logika rozwoju gospodarczego [in:] Obrębalski M. (red.), Gospodarka lokalna w teorii i praktyce, Wyd. AE, Wrocław 1996

[9] Dylewski M., Kierunki prowadzenia analizy finansowej w procesie zarzadzania finansami [in:] Finanse samorzadowe. Narzędzia, decyzje, procesy, red. M. Dylewski, B. Filipiak, M. Gorzałczyńska-Koczkodaj, Wyd. Nauk. PWN, Warszawa, pp. 144-151, 2006.

[10] Filipiak B., Analiza finansowa i jej znaczenie w zarządzaniu finansami [in:] Dylewski M., Filipiak B., Gorzalczyńska-Koczkodaj M., Finanse samorzadowe. Narzędzia, decyzje, procesy, Wyd. Nauk. PWN. Warszawa, pp. 138-143, 2006.

[11] Wojciechowski E., Zarzadzanie w samorzadzie terytorialnym, Warszawa, p. 234, 2012.

[12] Młodak A., Analiza taksonomiczna w statystyce regionalnej, Difin, Warszawa, pp. 28-32, 2006.

[13] Wysocki F., Lira J., Statystyka opisowa, Wyd. AR im. Augusta Cieszkowskiego w Poznaniu, Poznań, 2005.

[14] Kukuła K., Metoda unitaryzacji zerowanej. PWN, Warszawa, 2000

[15] Tokarski T., Statystyczna analiza regionalnego zróżnicowania wydajności, zatrudnienia $i$ bezrobocia w Polsce, Wydawnictwo PTE, Warszawa, 2005.

[16] Olak A., Zjawisko bezrobocia w Polsce [in:] A. Olak, E. Szymańska, A. Trzyna, Zmiany $w$ regionie $w$ warunkach globalizacji. Stowarzyszenie „Nauka, Edukacja, Rozwój” Ostrowiec Śs., 2013.

[17] Olak A., Pawlik A., Ksztatcenie ludzi dla właściwych zachowań organizacyjnych w sytuacjach zagrożenia [in:] A. Olak, A. Pawlik, Wrażliwość regionu na zmiany, WSBiP Wyd. „Nauka, Edukacja, Rozwój”, Ostrowiec Św., 2013. 
[18] Dukiewicz T., Spustek H., Informacja $w$ zarzadzaniu strategicznym [in:] ZN Politechniki Śląskiej, seria Organizacja i Zarządzanie, Politechnika Śląska, nr 92, pp. 61-71, 2016.

[19] Piwowarski J., Transdyscyplinarna istota kultury bezpieczeństwa narodowego, Wyd. Naukowe Akademii Pomorskiej w Słupsku, Słupsk, 2016. 